\title{
THE TECHNOLOGICAL PROPERTIES OF FLAX FIBERS ASSOCIATED WITH A DEVELOPED SEPARATING MACHINE Abou-Habaga, M.M. ${ }^{1}$; M.H.M.Abou-ELNaga ${ }^{2}$ and M.M.Ismail ${ }^{2}$ 1- Dept. of Agric. Eng., Fac. of Agric., Mansoura Univ. \\ 2- Agric. Eng. Res. Institute, Agric. Res. Center
}

\begin{abstract}
The aim of this work is to associate the main technological properties of flax fibers with a developed machine prototype. The determined results are necessary as a database to develop a simple machine for helping the Egyptian farmers in the process of flax fiber separation. A proper prototype was fabricated at a locally workshop at Meet-Ali, Dakahleia Governorate. The determined technological properties of long flax fibers were:- fiber percentage, fiber length categories, fiber fineness, and fiber strength. These properties were investigated as affected by different machinery, and crop variables such as: separating drum speed (of 1.58, 3.52 and $8.21 \mathrm{~m} / \mathrm{s}$ ), straw feeding rate (of $2.0,2.5$ and $3.0 \mathrm{~kg} / \mathrm{min}$ )., and straw moisture content (of $8.42,10.8$ and $12.6 \%$,wb).

The gained results reveled that;

- The best performance of the developed machine prototype, with respect to long fiber percentage $(14.32 \%)$, and to fiber length category $(78.99 \mathrm{~cm})$ were obtained at drum speed of $1.58 \mathrm{~m} / \mathrm{s}$, feeding rate of $120 \mathrm{~kg} / \mathrm{hr}$ and straw moisture content of $8.42 \%$.

- The best degree of fiber fineness $(129.74 \mathrm{~mm} / \mathrm{mg})$ was accomplished drum speed of $8.21 \mathrm{~m} / \mathrm{s}$, feeding rate of $120 \mathrm{~kg} / \mathrm{hr}$ and straw moisture content of $8.42 \%$. While, the best fiber strength (27.14 tex /gr ), was associated with drum speed of $1.58 \mathrm{~m} / \mathrm{s}$ feeding rate of $180 \mathrm{~kg} / \mathrm{hr}$ and straw moisture content of $12.6 \%$.
\end{abstract}

\section{INTRODUCTION}

In fact, farmers after mature stage of flax crop are doing many sequence processes such as pulling, tied, airing, thrashing, and retting, drying and straw breaking for fiber separation the transport deficiency for flax crop from field to collecting center, resulted in more dangers accidents, increasing of crop losses and reduce the proceeds for Egyptian farmer. In addition, the avoidance of a proper simple machine for processing of flax fiber separation which represent also a great problems for Egyptian farmers, and also affected the main technological properties of flax fibers. Momtaz (1965) found that the fiber length and fiber fineness were $61.45 \mathrm{~cm}$ and $74.54 \mathrm{Mm} / \mathrm{ml} . \mathrm{g}$ for fiber flax, respectively. Yanagisawa (1967) mentioned that decreasing light intensity reduced flax fiber percentage. EL-Farouk (1968) found that the fiber lengths of flax were $87.42 \mathrm{~cm}$, fiber percentages of flax were 13.8, and fiber fineness of flax were $124.00 \mathrm{Mm} / \mathrm{ml}$.g. EL-Hariri (1968) concluded that the fiber length of flax was $80.6 \mathrm{~cm}$. while its long fiber percentage was $28.3 \%$. $\mathrm{He}$ added that fiber strength and fiber fineness were $27.97 \mathrm{Rkm}$. and 133.9 $\mathrm{Mm} / \mathrm{ml} . g$. , respectively. Yousef (1968) stated that the fiber length, fiber percentage and fiber fineness for flax were $80.2 \mathrm{~cm}, 15.82 \%$ and 99.72 $\mathrm{Mm} / \mathrm{ml} . g$. , respectively. Bonte (1969) concluded that the quality of fiber flax 
grown in different regions differed from one field to another. He found that the best yarn was usually spun from reina variety in the France north than any other regions. Eweida et al. (1969) found that the fineness, strength and length of flax fiber were $40 \mathrm{Mm} / \mathrm{ml} . \mathrm{g} .6 .77 \mathrm{gm}$ and $60 \mathrm{~cm}$., respectively. Sizov (1970) mentioned that plants of fiber flax of region north parts had higher proportion of fiber and a considerably higher fiber quality compared with south regions. Friederich (1969) found that fiber flax gave $21.6 \%$ fiber percentage in 8 trials at various sits in Nether land; these were lower than usual because of wet weather.

In order to overcome the above mentioned problems the main objective of this work is to determine the technological properties of flax fibers, that it is necessary to develop a simple machine for separating flax fibers.

\section{MATERIALS AND METHODS}

The achieve aim of this work a simple machine for separation flax fibers, was fabricated at locally workshop at Meet - Ali - Dakahleia Governorate. The experiments for testing the developed machine were carried out through two successful season of 2007/2008 in Tag EL- EZZ Agricultural Research Station, Dakahleia Governorate.

\section{Materials}

\subsection{The developed machine:}

The sketch of developed machine is shown in Fig. (1). It was powered by an electrical motor (A.O.SMITH CROPORATION) of $3.728 \mathrm{~kW}$, and 1200 r.p.m, the motor power was transmitted through cone pulleys with diameter of 195, 140 and $85 \mathrm{~mm}$. The frame of the developed machine was with dimensions of $108.5 \times 61.0 \times 88.0 \mathrm{~cm}$ for length, width and height respectively. It was constructed from L-section steel of " $4 \times 4 \mathrm{~cm}$ ". Also eight smooth surface drums, each with a length of $48.00 \mathrm{~cm}$, diameter of $11.2 \mathrm{~cm}$ and mass of $12 \mathrm{~kg}$. In additions a four wings fan was fabricated from galvanized thin sheet iron with a length of $50 \mathrm{~cm}$, width of $20 \mathrm{~cm}$ and thick of $2 \mathrm{~mm}$, A proper power transmission pulley system was provided to obtain the desired drum speed as shown in Fig. (1).The pulleys were fabricated from aluminum. That transmission system included three groups of pulleys. The first groups have three pulleys with different diameters of 195, 140 and 85 $\mathrm{mm}$. The second and third included double similar pulleys. Each with a diameter of $100 \mathrm{~mm}$. A flax straw feeding gate (with dimensions was equipped at a high of $106 \mathrm{~cm}$ from ground surface in the front of developed machine. While, the fibers outlet gate was constructed at a high of $95 \mathrm{~cm}$ from ground surface at the end of develop machine with a dimensions of $50 x$ $52 \times 20 \mathrm{~cm}$ length, width and high respectively. Another outlet gate for wood particles was constructed in the right side of machine at a high of $105 \mathrm{~cm}$ from ground surface with dimensions of $30 \times 20 \times 10 \mathrm{~cm}$ length, width and high respectively.

\subsection{Variety of tested flax:}

Sakalana flax variety was used during performing the experimental tests. Whereas, fifty kg of flax straw were used during carried the tests. 


\section{Methods of measurements:}

To carry out the experiments, and to test the performance of developed machine, the following measurements were determined;

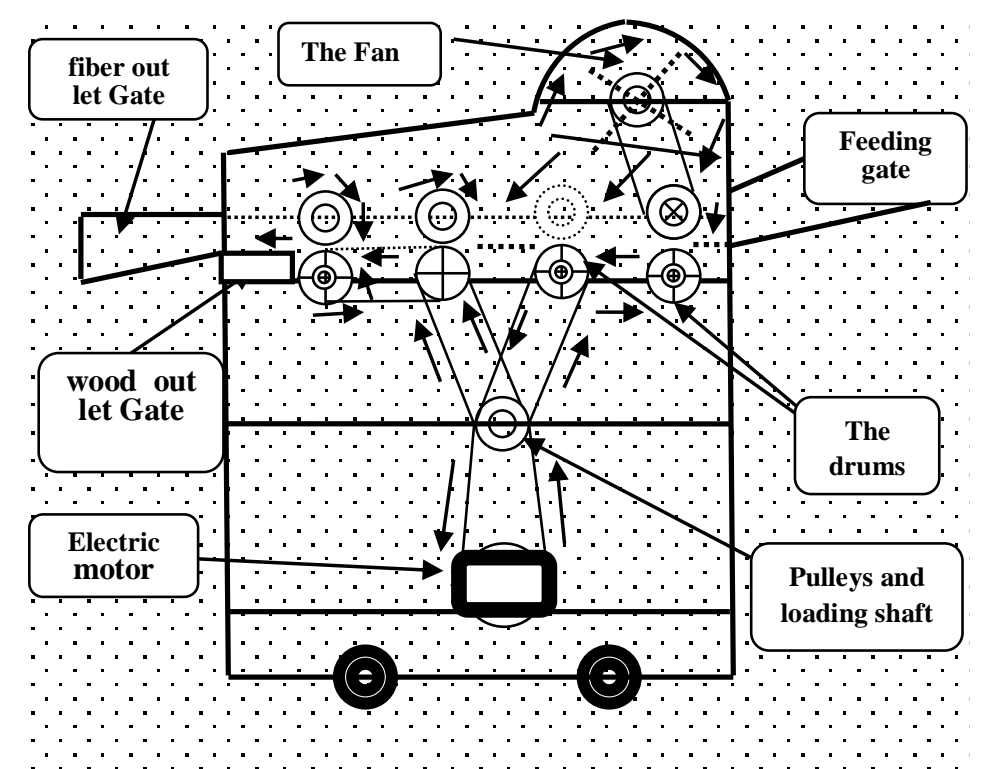

Fig. (1): The sketch of the developed machine for separation flax fiber

\subsection{Straw moisture content:}

Moisture content of flax straw was determined according to ASAE (1992) Standard ASAE S358 after retting process. The straw samples were taken randomly after 10,15 and 20 days from retting time. These samples were drying by oven at $70 \mathrm{C}^{0}$ for 24 hours. The straw moisture content, (\%) was calculated as follows:

$$
M=\frac{M_{w s}-M_{d s}}{M_{w s}},
$$

Where:

$$
\begin{aligned}
M & =\text { straw moisture content, } \% \\
M_{w s} & =\text { set straw weight, } \mathrm{g} . \\
M_{d s} & =\text { dry straw weight, } \mathrm{g} .
\end{aligned}
$$

\subsection{Drum speed:}

Speedometer was used to measure the rotary speed of the electricity motor shaft and drums.

\subsection{The sample weights:}

A spring and digital electronic balances were used to measure the sample weights of each flax straw, wood partecles and fibres produce. 


\section{4. Long fiber percentage:}

Fibers are considered long categories, if the fiber length at length ranges of $>80 \mathrm{~cm}$. The percentage by weight of long fibers was estimated using the following equation.

$$
L_{f}=\frac{W_{f}-S_{f}}{W_{f}},
$$

Where:

$$
\begin{aligned}
L_{f} & =\text { long fiber percentage, } \% \\
W_{f} & =\text { total fibers weight, } \mathrm{kg} \\
S_{f} & =\text { short and small fibers weight, } \mathrm{kg}
\end{aligned}
$$

\subsection{Fiber length:}

it was measured by using a scale meter.

\subsection{Fiber fineness:}

The degree of fiber fineness $(\mathrm{Ff}$.) was determined according to Radwan and Momtaz (1966), using the following formula

Where:

$$
\mathrm{Ff}=(\mathrm{N} \times \mathrm{L}) / \mathrm{G}
$$

$$
\begin{aligned}
\mathrm{Ff} & =\text { fiber fineness, } \mathrm{mm} / \mathrm{ml} . \mathrm{g} . \\
N & =\text { Number of } 20 \text { fibers tested fibers }(\text { each } 10 \mathrm{~cm} \text { ) } \\
\mathrm{L} & =\text { Length of tested fibers in, } \mathrm{mm}(2000) . \\
\mathrm{G} & =\text { weight of tested fibers in, ml.g. }
\end{aligned}
$$

\subsection{Fiber strength:}

Pressely implement-Code 231A was used to estimate the fiber strength (FS) as shown in Fig. (2) The measurements were performed at textile department Laboratory at faculty of Engineering-Al-Mansoura University. (FS) was determined according to Radwan and Momtaz (1966), using the following formula;

\section{Where;}

$$
F S=\left(N \times L \times C_{t}\right) / G
$$
FS = fiber strength. $\mathrm{mm} \mathrm{N} / \mathrm{ml} . \mathrm{g}$.
$\mathrm{N}=$ Number of 20 fibers tested fibers (each $10 \mathrm{~cm}$ ).
$\mathrm{L}=$ Length of tested fibers in, $\mathrm{mm}$ (2000).
$\mathrm{C}_{f}=$ Mean of the tensile force for breaking an individual fiber,N.
$\mathrm{G}=$ weight of tested fibers in, $\mathrm{ml} . \mathrm{g}$. 


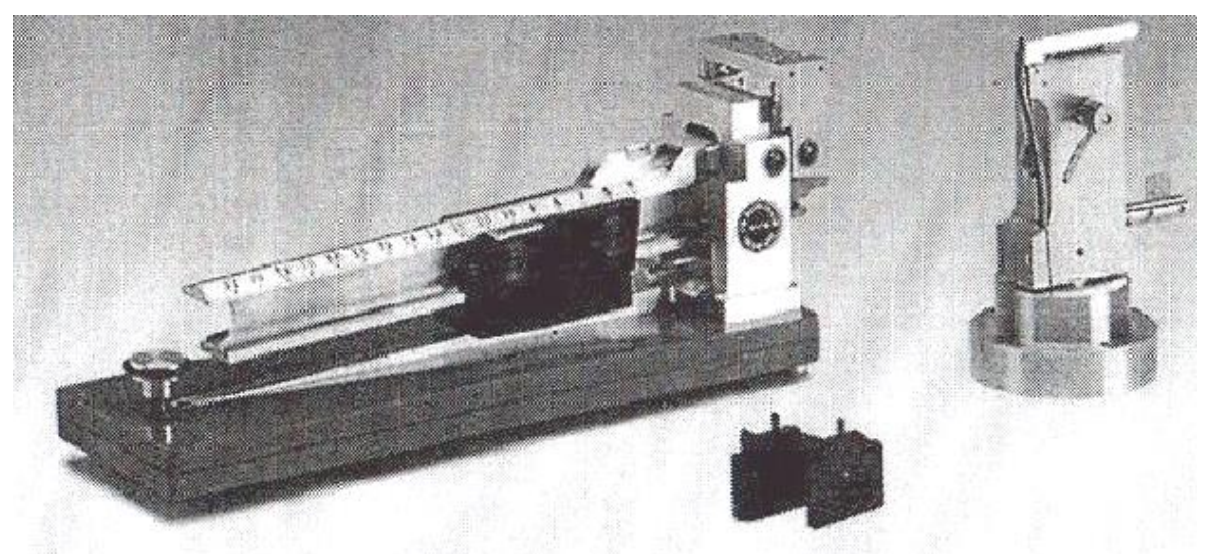

Fig. (2): Implement uses for determined the tensile force for breaking an individual fiber (Pressley - Code $231 \mathrm{~A}$ ).

\section{RESULTS AND DISCUSSION}

\section{The long fiber percentage:-}

Data in Fig. (3) Illustrate the long fiber percentages as affected by different drum speed, straw feeding rates, and straw moisture content. Analyses, these data revealed that, long fiber percentage of fiber flax have a liner relation between drum speeds and other parameters under studies. The corresponding regression equations and correlation coefficients for each individual curve are also included in Fig. (3). These results indicated that as increasing of drum speed from 1.58 to 3.52 or to $8.21 \mathrm{~m} / \mathrm{s}$, the long fiber percentages were decreased by $(1.95,1.79$ and $1.64 \%),(1.78,1.77$ and $1.55 \%)$ and (1.55, 1.47 and $1.26 \%$ ) under feeding rates of 120,150 and 180 $\mathrm{kg} / \mathrm{hr}$ and straw moisture content of $8.42 \%, 10.8 \%$ and $12.6 \%$ respectively. That result trend may due to the value of friction forces between flax straws themselves and friction between flax and drum surface. However the highest long fiber percentage $14.32 \%$ was obtained at drum speed of $1.58 \mathrm{~m} / \mathrm{s}$, feeding rate of $120 \mathrm{~kg} / \mathrm{hr}$ and straw moisture content of $8.42 \%$, while the lowest $13.61 \%$ was obtained at drum speed of $8.21 \mathrm{~m} / \mathrm{s}$, feeding rate of 180 $\mathrm{kg} / \mathrm{hr}$ and straw moisture content of $12.6 \%$. From Fig. (3), it may be concluded that the effects of the studied variables on that fiber prosperity can be arranged as follows: - the diamond is drum speed, followed by straw feeding rate, came at the end the straw moisture content.

\section{Long flax fiber length categories:-}

Data in Fig. (4) Clarify the combined effects of drum speed on long fiber length of fiber flax, and as affected by different feeding rates and straw moisture contents. The regression analyses of data revealed that, long fiber percentages have a liner relation between drum speeds and other parameters under studies. Also, the regression equations and correlation coefficient of mentioned data are included in Fig. (4). 


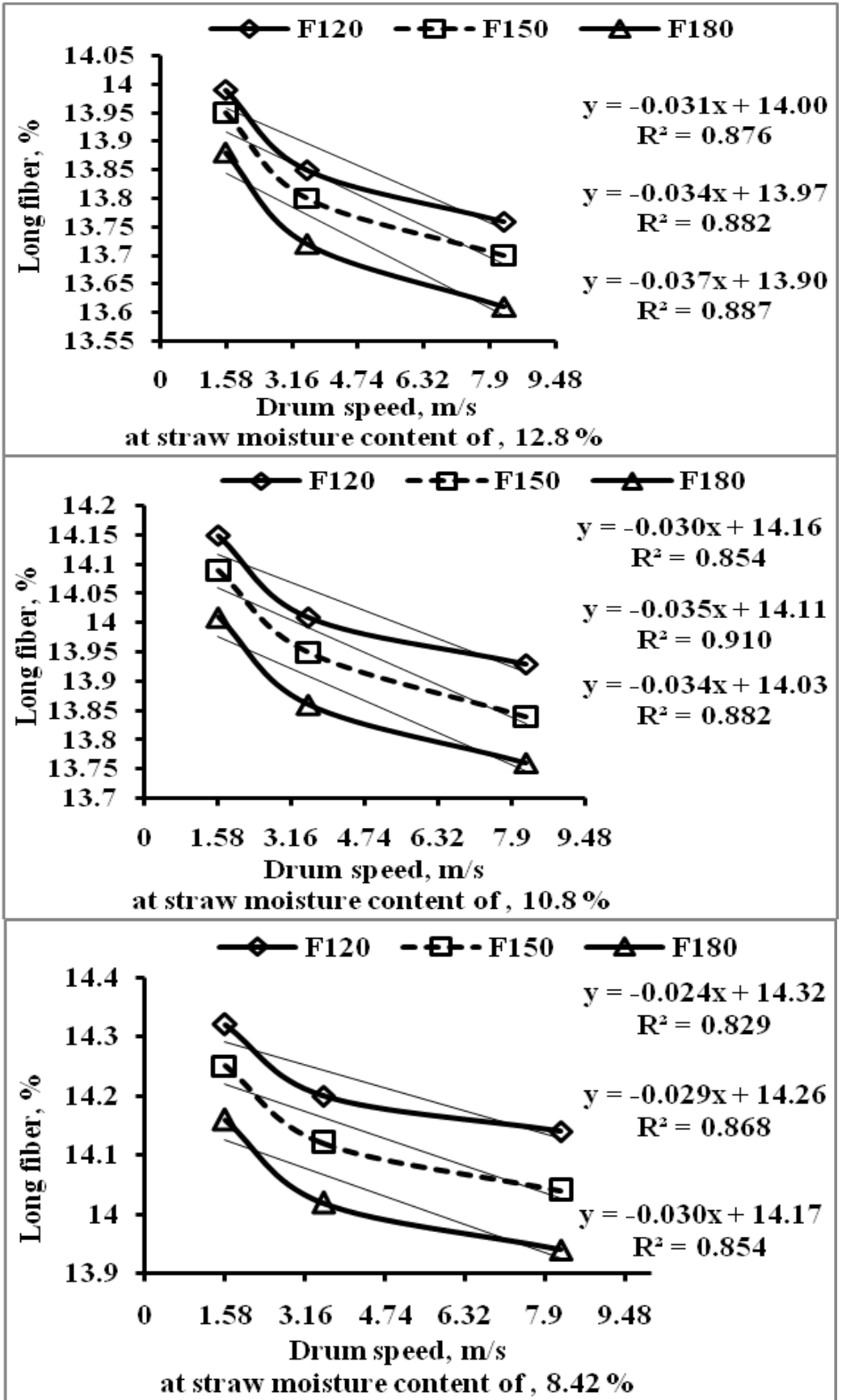

Fig. (3): The long fiber percentages as affected by drum speeds, straw feeding rate, and straw moisture 


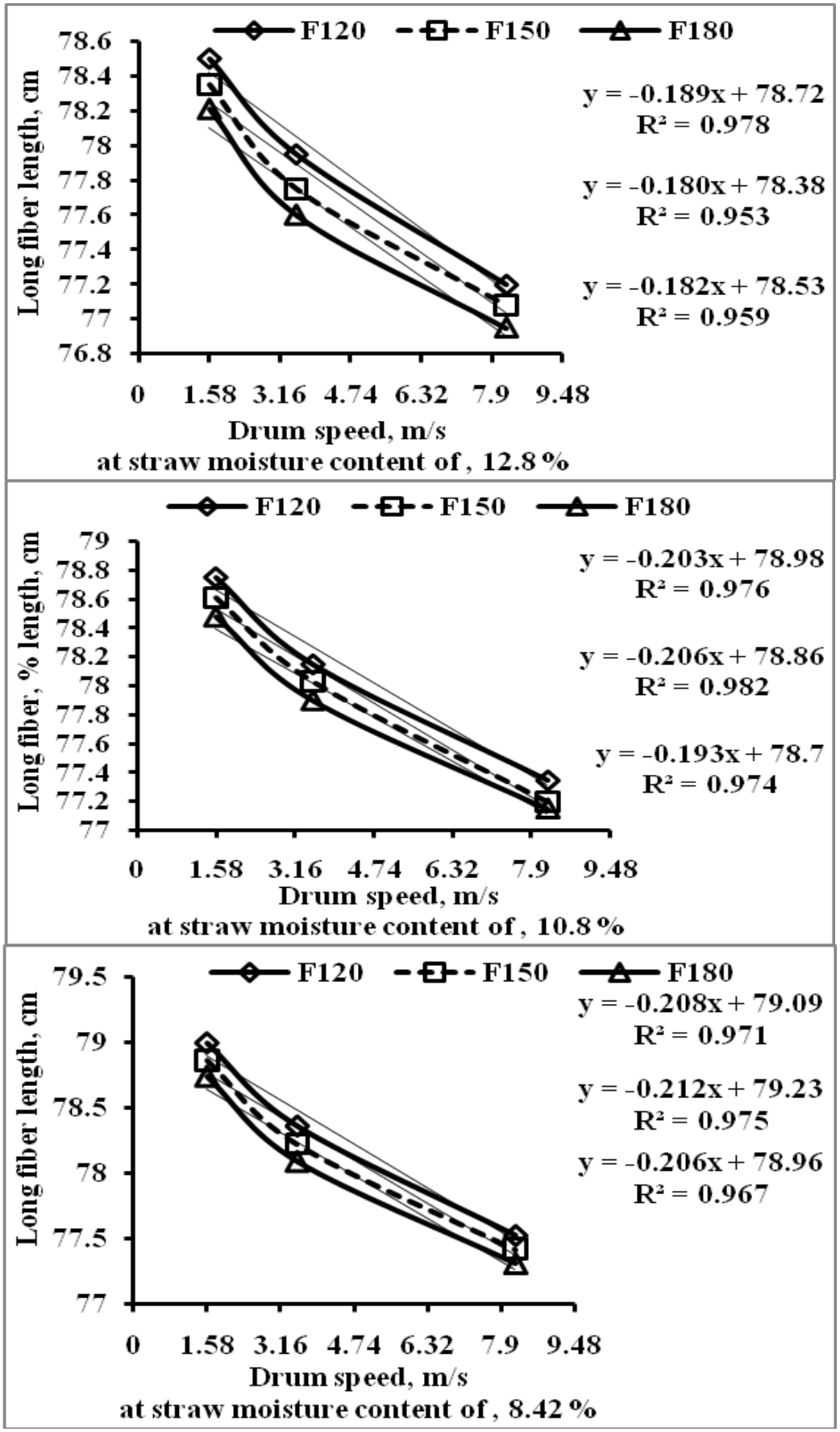

Fig. (4): Flax fiber length (cm) as affected by drum speed, straw feeding rate and straw moisture content. 
It can be seen that by increasing drum speed from 1.58 to 3.52 and 8.21 $\mathrm{m} / \mathrm{s}$, the long fiber length decreased by $(1.85,1.83$ and $1.82 \%),(1.78,2.56$ and $1.67 \%)$ and $(1.66,1.62$ and $1.61 \%)$ under feeding rates of 120,150 and $180 \mathrm{~kg} / \mathrm{hr}$ and straw moisture content of $8.42 \%, 10.8 \%$ and $12.6 \%$ respectively. The decrements in fiber length as the drum speed increased may be attributed to the same previous mentioned reason causes in long fiber weight percentage. However, the highest value of long fiber length $78.99 \mathrm{~cm}$ was obtained at drum speed of $1.58 \mathrm{~m} / \mathrm{s}$, feeding rate of $120 \mathrm{~kg} / \mathrm{hr}$ and straw moisture content of $8.42 \%$, while the lowest value of long fiber length $76.95 \mathrm{~cm}$ was obtained at drum speed of $8.21 \mathrm{~m} / \mathrm{s}$ feeding rate of 180 $\mathrm{kg} / \mathrm{hr}$ and straw moisture content of $12.6 \%$. From Fig. (4), it may be also arranged the effects of the studied variables on that long fiber length as follows: - the diamond is drum speed, followed by the straw moisture content came at the end straw feeding rate as the lowest effect.

\section{The degree of fiber fineness}

The estimated data of the degree of fiber fineness are indicated in fig. (5).These data are drawn as affected by drum speeds feeding rates and straw moisture content. Referring the data shown in Fig. (5) Revealed that there were regular increments in the degree of fiber fineness were happened as drum speed increased. Inverse result trend could be observed as any of feeding rate and straw moisture was increased. Whereas, regular increments in the degree of fiber fineness were happened as any of feeding rate and straw moisture were decreased from the upper to the lower investigated level, the variables under study was increased from the lower to the upper investigated level, the increment rates in fiber fineness due to drum speed increasing from 1.58 to 3.521 and $8.21 \mathrm{~m} / \mathrm{s}$, were $(0.22,0.19$ and $0.18 \%),(0.21,0.19$ and $0.20 \%)$ and $(0.22,0.20$ and $0.17 \%)$ under feeding rates of 120,150 and $180 \mathrm{~kg} / \mathrm{hr}$ and straw moisture content of $8.42 \%, 10.8 \%$ and $12.6 \%$ respectively. However, the highest value of the fineness degree $(129.74 \mathrm{~mm} / \mathrm{ml} . \mathrm{g})$ was obtained at drum speed $8.21 \mathrm{~m} / \mathrm{s}$, feeding rate of 120 $\mathrm{kg} / \mathrm{hr}$ and straw moisture content of $8.42 \%$, while the lowest value $(126.63$ $\mathrm{mm} / \mathrm{ml} . \mathrm{g}$ ) was obtained at drum speed of $1.58 \mathrm{~m} / \mathrm{s}$, feeding rate of $180 \mathrm{~kg} / \mathrm{hr}$ and straw moisture content of $12.6 \%$.

\section{Fiber strength:}

The strength of resulted fiber was estimated according equation (5), and the averages of the obtained data are presented in Fig. (6).It can be seen that long fiber strength was affected by the changes of drum speed, feeding rates and straw moisture content. The data analyses revealed that that the increasing of drum speed from 1.58 to 3.52 and $8.21 \mathrm{~m} / \mathrm{s}$, the long fiber strength increased by $(0.35,0.43$ and 0.35$),(0.34,0.46$ and $0.34 \%)$ and $(0.33,0.41$ and $0.33 \%)$ under feeding rates of 120,150 and $180 \mathrm{~kg} / \mathrm{hr}$ and straw moisture content of $8.42 \%, 10.8 \%$ and $12.6 \%$ respectively. 

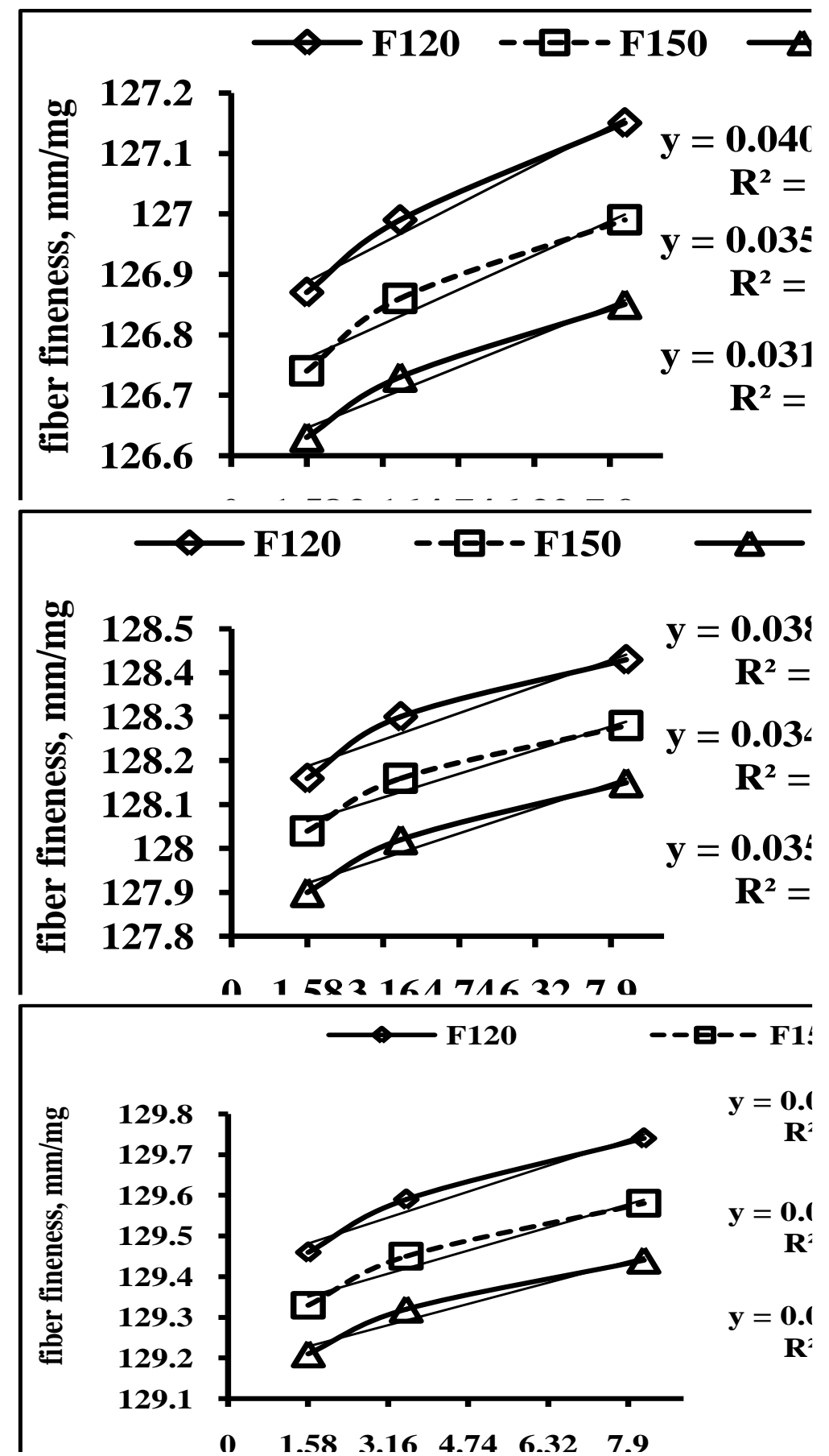

Fig. (5): The degree of fiber fineness as affected by drum speed, straw feeding rate and straw moisture content 

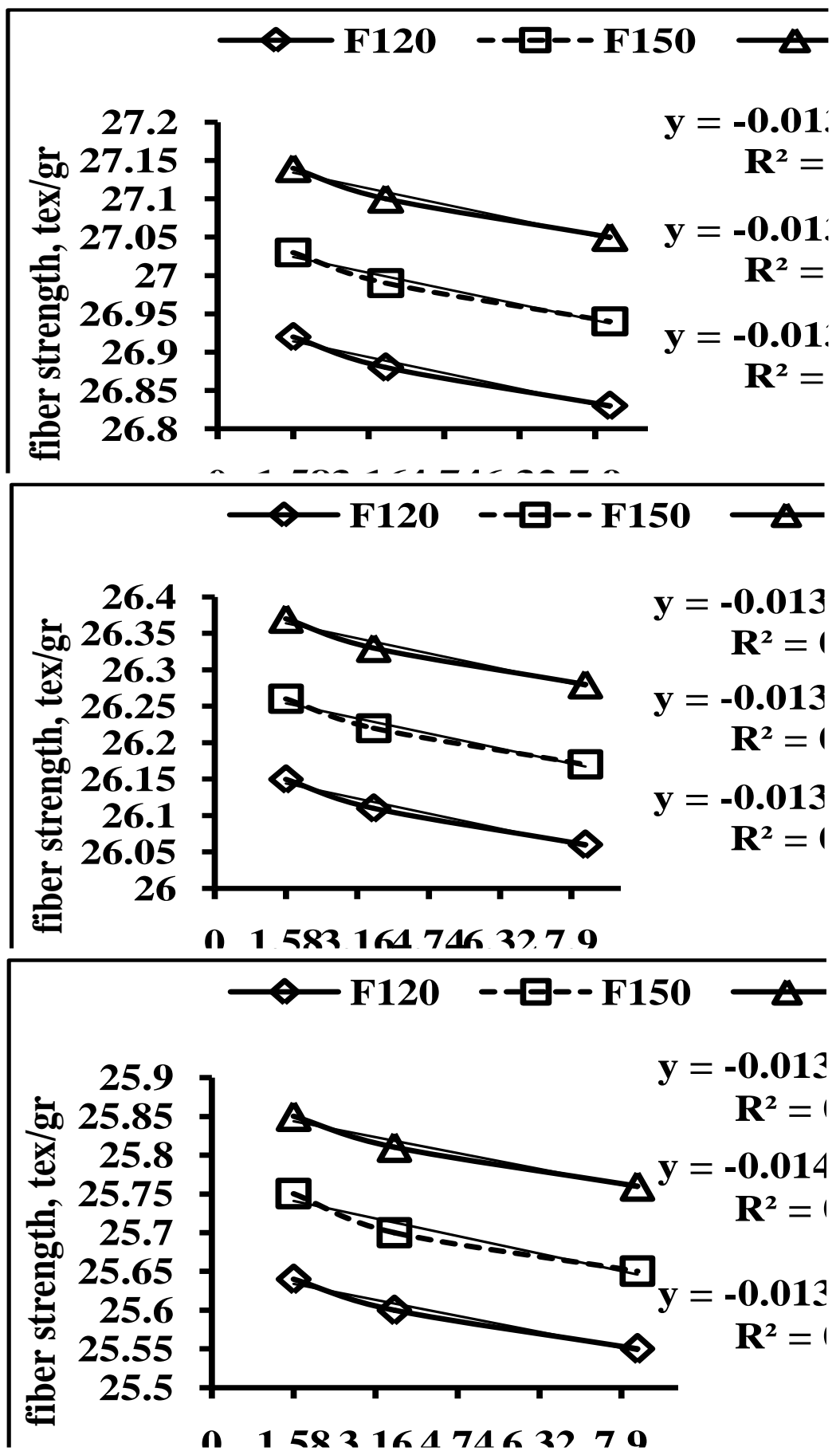

Fig. (6): Fiber strength as affected of drum speed, straw feeding rate and straw moisture content. 
The regression analysis of the data showed liner relation between strength of fiber and drum speeds and other parameters under study. However, the highest value of long fiber strength 27.14 was obtained at drum speed of $1.58 \mathrm{~m} / \mathrm{s}$ feeding rate of $180 \mathrm{~kg} / \mathrm{hr}$ and straw moisture content of $12.6 \%$, while the lowest values of long fiber strength of fiber flax 25.55 was obtained at drum speed of $8.21 \mathrm{~m} / \mathrm{s}$, feeding rate of $120 \mathrm{~kg} / \mathrm{hr}$ and straw moisture content of $8.42 \%$.

\section{Conclusions}

To determine the necessary database for developing a simple machine for helping the Egyptian farmers in the process of flax fiber separation, a proper prototype was developed and its fiber separation performance was evaluated. The prototype performance was evaluated in terms of the main technological properties and as affected by different machinery, and crop variables such as: separating drum speed, straw feeding rate and straw moisture content.

\section{The following conclusions may be drawn:}

- The best long fiber percentage $14.32 \%$, and the best long fiber length $78.99 \mathrm{~cm}$ were obtained as drum speed was of $1.58 \mathrm{~m} / \mathrm{s}$, feeding rate was of $120 \mathrm{~kg} / \mathrm{hr}$ and straw moisture content was of $8.42 \%$

- The proper fiber fineness $(129.74 \mathrm{~mm} / \mathrm{ml} . \mathrm{g}$ )and promise fiber strength $(27.14 \mathrm{~N} . \mathrm{mm} / \mathrm{ml} . \mathrm{g}$ ) associated with developed machine were obtained respectively at drum speed 8.21 , and $1.58 \mathrm{~m} / \mathrm{s}$, feeding rate of 120 , and $180 \mathrm{~kg} / \mathrm{hr}$ and straw moisture content of 8.42 ,and $12.6 \%$,

\section{REFERENCES}

ASAE Yearbook Sandard (1992) Agricultural engineers year-book. ASAE. St. Joseph, Ml., S303.1, S269,S358.

Bonte, E. (1969) Spinning behavior of different varieties of flax. Fibra. 14 : No. 1.3 - 22. (c.f. Field Crop Abst. 1971, 24: 2495).

EL-Farouk, M.M.A.(1968) Effect of plant density, Nitrogenous fertilizer and irrigation on yield and fiber quality of flax (Linum usitatissimum L.) M.Se. Thesis, Faculty of Agric., Cairo Univ.

EL-Hariri, D.M. (1968) Factors affecting quality of flax yield. Ph.D. Thesis, Faculty of Agric., Ain Shams Univ.

Eweida, M.H.T.;H.Salem and M.Ghanem.(1969) Cellulose content in Egyptian cotton, flax and hemp. Ann. Agric. Sci. No. 150.

Friederich, J.C.(1969) Results of flax harvest and flax varietal trials in 1968. Meded. Ned. Alg. Keur Dienst Zoaizaad Pootg. Landb. Gewoss. 1969, 26, No. 1, 5 - 6. (c.f. Field Crop Abst. 1971, 24: 2493).

Momtaz, A.(1965) Analytical and inheritance stuies on economic characters of flax. M.Se. Thesis, Faculty of Agric., Cairo Univ.

Pasila, A. (1999) The effect of frost on fibre plants and their processing. Mol. Cryst. And Liq. Cryst. 353: 11- 22. Sisäilmaohje. Sosiaali- ja terveysministeriön oppaita 1997:1. Helsinki. 


\section{Abou-Habaga, M. M.et al.}

Radwan,S.R.H. and A. Momtaz (1966) The technological properties of flax fibers and the methods of estimating them. El-Felaha Jour. 46(5): 466476. (In Arabic).

Sizov, I.A. (1970) On the evaluation and geneties of (Linum usitatissimum L.) Trudy prikl. Bot. Genet. Selek. $42: 3$ - 19. (c.f. Field Crop Abst. 1971, 24: 1124).

Yanagisawa, Y.(1967) Effets of shading on the growth and some properties of fiber cells of flax plant, (Linum usitatissimum L.) Proc. Crop Sci. Soc. Japan. 32, No. 3, $229-232$.

Yousef, M.A. (1968) Effect of sowing and harvesting dates on yield and fiber quality of flax (Linum usitatissimum L.) M.Se. Thesis, Faculty of Agric., Cairo Univ.

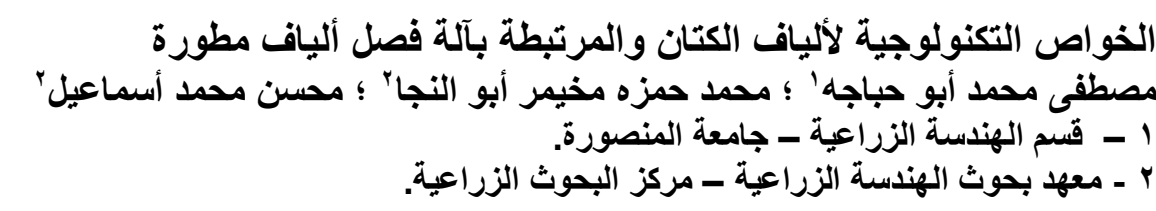

نظر الصعوبة نقل محصل الكتان وما يترتب عليه من حوادث و الزيادة فى فو اقد المحصول من بذور وفش و إنخفاض العائد الربحى للمز ارع المصرى ولمعظمة العائد الربحى للمز ارع هن هناك عمليات عدة يستطيع

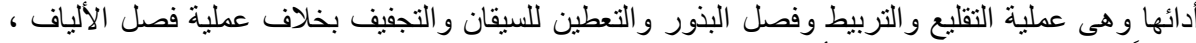

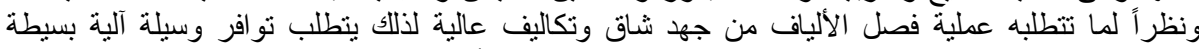
وميسرة تكون فى متناول المزارع تساعده فى عملية فصل ألياف الكتان مع الحفاظ على الخى الخصائص

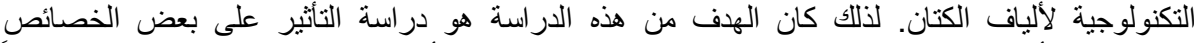
التكنولوجية لألياف الكتان والمرتبطة بآلة مطورة وبسيطة لفصل ألياف الكتان تم نشكيلها وضبطها فنياً

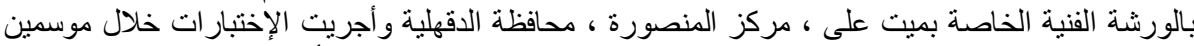

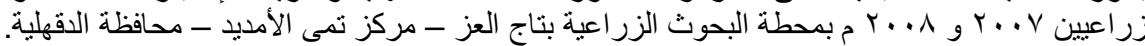
وتمثلت الخصائص التكنولوجية لألياف الكتان فى (نسبة الألياف الطويلة ، الطول للألياف الطويلة ، درجة درية

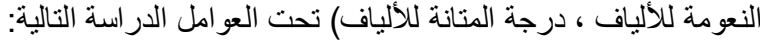

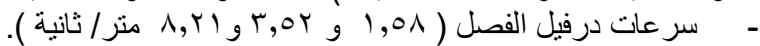

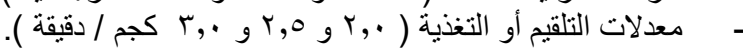

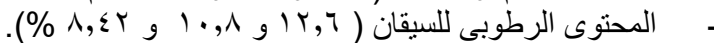

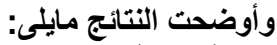

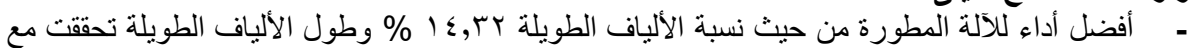

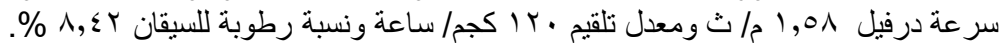

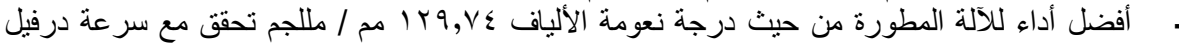

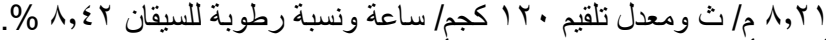

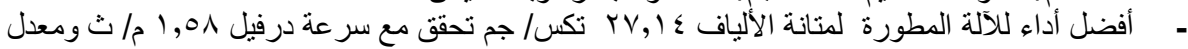

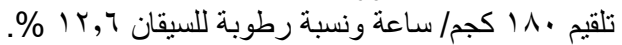

